\title{
Truth and Reconciliation in South Africa: Jewish Voices and Perspectives
}

\author{
P G J Meiring \\ (University of Pretoria)
}

\section{ABSTRACT}

\section{Truth and Reconciliation in South Africa: Jewish Voices and Perspectives}

The author who served on the South African Truth and Reconciliation Commission (TRC) focuses on the Jewish experience in South Africa during the apartheid years. At a special TRC Hearing for Faith Communities (East London, 17-19 November 1997) Chief Rabbi Cyril Harris submitted a statement on behalf of his community. Two earlier documents were also put at the TRC's disposal: a statement on Reconciliation presented by Gesher (a Jewish movement for social action) as a well as a comprehensive volume containing 27 interviews with Jewish activists (Cutting Through the Mountain). Taking his cue from both the Chief Rabbi's presentation and the earlier documents, the author discusses the role of the Jewish community in overtly and covertly supporting the apartheid regime, as well the experiences of many Jews in struggling against apartheid. Finally the contribution of the Jewish community towards healing and reconciliation in South Africa comes under the spotlight.

\section{INTRODUCTION}

It seemed fitting to all that Chief Rabbi Cyril Harris was called to the podium, to present the local Jewish community's testimony before the South African Truth and Reconciliation Commission (TRC). For many years - since his coming to South Africa in 1988 - he was recognized as one of the more vocal leaders within the family of faith communities in the country, openly supporting the struggle against apartheid. His strong statements invariably reached the press. His imposing figure was often seen on television, leading yet another demonstration through the streets of Johannesburg and Cape Town, his arms linked with the arms of Desmond Tutu, Frank Chikane and Beyers Naudé.

The auditorium in East London was packed. The audience who came from wide and afar to share the three days set aside for faith communities in South Africa to appear before the Truth and 
Reconciliation Commission (17-19 November 1997), was not disappointed. Eminent church leaders took turns to address the Commission. So did representatives from the Muslim, Buddhist, Hindu and Baha'i communities, as well as spokespersons from traditional African religious communities. Now the moment has come for the Jewish community to have its say. What would the Chief Rabbi of South Africa report on the experience of the Jewish community during the apartheid years in South Africa?

During the course of its work the South African Truth and Reconciliation Commission (1996-1998) invited thousands of victims of gross human right violations - as well as political leaders, security force personnel, military officers and activists guilty of perpetrating these acts - to present their statements to TRC commissioners at 140 hearings held in many parts of the country. When that was finished, the TRC requested representatives of special interest groups - the medical fraternity, the lawyers, the media, big business, academic institutions, political parties, the police and correctional services, women's groups, black youth who suffered during the past - to do the same. The very last event in the series of 'special hearings' was devoted to the faith communities. The hearings were held in the port city of East London, the venue where 17 months earlier the first TRC victims' hearing took place. Archbishop Tutu was delighted with the occasion. "Probably the best of all the TRC hearings", he called it (Meiring 1999:265; cf Tutu 1998:177ff; Boraine 2000:179ff).

It was, however, not without serious debate that the event indeed took place. Some TRC commissioners questioned the wisdom of having such a hearing. Surely the faith communities even the Afrikaans churches which for many years openly supported the policy of apartheid - were not guilty of gross human rights violations? What would they confess to? But, countered the rest of the TRC commissioners, the churches as well as the other faith communities were so closely involved in everything that happened in South Africa, on both sides of the struggle, that it was inconceivable not to invite them to speak (Meiring 1999:266). The pastors and the priests, the bishops and the moderators, the imams and the rabbi's, needed an opportunity to tell their stories: stories of guilt and of shame, of pain and suffering, also stories of courage and conviction, of forgiveness and reconciliation. 
Invitations were sent to the leaders of all the major Christian denominations in the country, as well as to the leadership of the other religious communities in South Africa. The vast majority accepted without hesitation - among them Rabbi Cyril Harris. As was the case with all the other speakers, Harris was asked to address primarily four questions: To what extent did the Jewish community suffer under apartheid? Were there some among them who overtly or covertly supported the system? Was the community - or some within the community - involved in the struggle against apartheid? Lastly, what contributions may be expected from the Jewish community in the process of nation building and reconciliation?

Cyril Harris' statement, Submission by the Jewish Religious Community, was not the only document put before the TRC. Already in January 1997, eleven months before the faith community's hearing, Geoff Sifrin submitted a document prepared by Gesher (a Jewish Movement for Social Action) titled Reconciliation - a Jewish View. And in May 1997 a comprehensive volume, Cutting Through the Mountain, was published under the editorship of Immanuel Suttner, containing interviews with 27 South African Jewish Activists. In the paragraphs below, in discussing the contribution towards reconciliation in South Africa, mention will be made of all three documents.

\section{THE JEWISH COMMUNITY IN SOUTH AFRICA}

Before that can be done, it is necessary to have some idea of the roots of the local Jewish community, and of the role played by thousands of Jewish men and women in South Africa. The Jewish Community, rabbi Harris reminded his TRC audience, was always relatively small. It never exceeded 4 percent of the white population. They were also, relatively speaking, new comers to this part of the world. That was the case indeed.

History tells us that while Dutch settlers arrived in the Cape as far back as 1652, with the arrival of Jan van Riebeeck and his party, it took the Jewish community almost two centuries longer, to establish themselves. There was a reason for that. Holland, in the $17^{\text {th }}$ century was Protestant territory, and the Dutch East India Company would only allow good solid Dutch Reformed burghers to settle in the Cape. It was only in 1806 with the English occupation of the Cape Colony, that Jews were welcomed to this part of Africa. Initially the Jewish community was small, with little impact in wider 
society. By 1840 , however, the numbers have grown sufficiently to celebrate, for the fist time, the Day of Atonement in Cape Town. Shortly afterwards the first synagogue, the Great Synagogue, was founded in the Gardens, in Cape Town (Meiring1996:103).

In the years that followed Jewish settlers established themselves not only in the Cape, but also in the Orange Free State and in Natal. With the discovery of diamonds in Kimberley (1867) and gold in the Transvaal (1873) a substantial number of Jewish businessmen as well as prospectors from England and Central Europe made their way to South Africa. Since 1880 the majority of Jewish immigrants arrived from Lithuania, most of them to become shopkeepers, transport riders and pedlars. The religious approach of the Lithuanians - traditional rather than strictly orthodox - and their strong Zionist convictions exerted a major influence on the local Jewish community. At the turn of the $20^{\text {th }}$ century two Jewish Boards of Deputies were established. In Natal (1903) and Cape Town (1904) to fend for Jewish interests in South Africa (Meiring 1996:103)

During the 1930s and 1940s when anti-Semitic political organizations like the Ossewa-Brandwag and the Gryshemde ("Grey Shirts") appeared on the South African scene, the United Board of Deputies played a major role in countering anti-Jewish slogans and demonstrations, fostering good relations with the wider - mostly white - community. Since the Second World War the role of the Jewish community has been taken for granted in nearly every sphere of life: in trade and industry, in education, law, research, culture, and sport. In the political arena Jews were to be found on both sides of the apartheid divide, sometimes to the delight and often to the irritation of the apartheid government (Suttner 1997:556). The creation of the new state of Israel (1948) was enthusiastically supported by the vast majority of South African Jews, and the South African government was among the first to officially recognize the independent state - and in later years to co-operate with the Israelis in many different ways.

In recent years the numbers of Jews in South Africa have dwindled. Many have left for financial and professional reasons, others because of crime and corruption in the country. Those who have stayed behind are as active as ever in the community. According to the 1996 national census 68060 South Africans have registered themselves under the rubric Jewish Faith/Hebrew: 55733 
Whites, 10,447 Blacks, 1058 Coloureds, 360 Indians, and 103 'others' (Hendriks and Erasmus 2002:18).

\section{JEWISH SUPPORT FOR APARTHEID}

The first question Rabbi Harris addressed was whether the theology and activities of the South African Jewish community contributed to the formation of the motives and perspectives of those responsible for gross human rights violations in South Africa, either in upholding the system of apartheid, or in opposing it.

\section{Guilty of apartheid abuses?}

Harris' answer left little doubt. Jewish theology can never be blamed for human rights abuses. To the contrary: Jewish religion teaches that human beings should pursue justice and that everyone should love their neighbour as themselves.

Judaism affirms that as everyone is created in the image of God, the union of the human family subsumes an inherent responsibility at all times and in all places to behave in a proper and virtuous manner. According to Jewish interpretation, in no manner can the Bible be used to justify the political, economical or social domination of any group over another. No encouragement whatsoever to commit human rights violations appears in Jewish sacred sources, quite to the contrary, but some may well have fallen short of the standards that Judaism sets (Harris 1997:269)

On the accompanying question whether the Jewish community helped create a climate for apartheid abuses, Harris was forthright: "The Jewish community certainly did not contribute to creating such a climate" (Harris 1997:269). He was, however, willing to acknowledge the fact that many in the community did not speak out strongly enough, when they might have been expected to do so. But one has to remember that they were part of a small community, immigrants in a foreign country, often feeling very insecure about their own position.

One must remember that the Jews came to South Africa as immigrants, leaving the lands of their birth due to economic and political persecution based in the main upon discrimination against their faith. Feelings of insecurity as a vulnerable minority group were 
subsequently exasperated by the trauma of the Holocaust and by the threat of anti-semitism on the part of the ruling National Party which had spearheaded the discriminatory immigration legislation of the 1930s that effectively ended Jewish entry into this country from Europe. Nevertheless, while this may help explain the caution of the Jewish community in the early apartheid years, in subsequent years many Jewish voices were raised against injustice. Any indictment of Jewish moral failure to speak up collectively as a community must also take into account the fact that the Jews were such a small community - never more than $4 \%$ of the white population - that the felt that they could not have made any notable difference to the situation, while there was always the fear of a resurgence of state-sponsored antisemitism (Harris 1997:269)

It is of interest to note that a number of Harris' compatriots, many of whom were actively involved in the struggle against apartheid (see paragraph 4 below) were not as willing as the chief rabbi to exonerate their fellow Jews in this regard. Helen Suzman, Joe Slovo, Ronnie Kasrils, Chief Justice Arthur Chaskalson, Albie Sachs, and many others rue the fact that the Jewish Community in general, and the Jewish Board of Deputies in particular, did not speak out sooner, and stronger, against the atrocities perpetrated by the apartheid regime (cf Meiring 1999:132).

Helen Suzman in an interview with Geoff Sifrin spoke for many of her fellow opponents of apartheid:

...I thought that the Jewish Board of Deputies should have spoken up more against apartheid. Of course they have changed over the last ten years, and became very much more outspoken in their condemnation. Prior to that I think they were just dead scared to bring the Jews under the beady eye of people like Dr Verwoerd, who were outspokenly anti-Semitic (Suttner 1997:431).

It was not only a question of fear. The Jews were very much part of a privileged part of society:

(The) Jews were always white here. Therefore they were part of the privileged class regarding the franchise, entering the professions, and so on. Many of them have 
done extremely well here. The social ostracism against the Jews came not from the government but from the English-speaking South Africans. It was a social thing for them - they didn't want Jews in clubs and so on, though there was a religious aspect as well - the Christian aspect (Suttner 1997:432f).

From time to time rabbis did speak out against apartheid, often against the wishes of their peers, and were strongly criticized by the Board of Deputies - who only took a grudging anti-apartheid stance late in the day (Suttner 1997:616) - for their trouble. Jewish leaders in the labour movement and in the political arena suffered a similar fate (Suttner 1997:8ff, 231). This, however, does not mean that the activists themselves were free of racial prejudice. Joe Slovo relates the fact that in the early 1940s, when a number of Jews joined the Communist Party, never a word was spoken about the fate of "all the black South African proletariat from whose exploitation we were all benefiting in one form or another" (Suttner 1997:229).

After 1990 it has become fashionable in the white community, also among Jewish South Africans, to identify with the pioneers and prophets of the past who warned against racism and apartheid. On the way in which Jews are nowadays sharing in the limelight of activists and the heroes of the struggle, Ronnie Kasrils remarked: "The Jewish community has lionized these individuals to some extent now that it is kosher to do so, but in the past many of them were condemned as people who were bringing notoriety to the community" (Suttner 1997:280).

\section{The South African-Israel connection}

A bone of contention during the apartheid years - as indeed it is still today - was the close relationship that developed between the South African National Party government, and the new independent state of Israel, since 1948. Could the close diplomatic, economic, technological, and especially military ties, ties that were generally welcomed by the South African Jewish community, be construed as Jewish support of the system of apartheid?

Chief Rabbi Harris did not make mention of the South AfricanIsraeli connection in his statement, but virtually all the activists interviewed in Cutting Through the Mountain did. Arthur Chaskalson spoke about his distress in this regard: 
...I felt Israel's identification with the apartheid government in South Africa was absolutely wrong. I understand realpolitik, but I think there are limits to what one should do. I think it was simple expediency. At the time, Israel was deeply isolated, and South Africa was isolated, they needed support from each other in certain fields, and they got into bed together because there was nobody else to get into bed with. That upset me (Suttner 1997:332).

Ronnie Kasrils told of contacts he has had with Israeli army officers recently, adding that they seem to be somewhat embarrassed by their past relationship with the South African government:

I think now they're a little shamefaced about helping SA to the extent they did during the worst period of apartheid. They really saved this country's bacon which was why Vorster and P W Botha became such strong allies...Israel has come to South Africa's rescue in terms of weapon supplies, and South Africa subsequently came to Israel's support with weapon supplies of a different kind, especially after the Yom Kippur War, and from then on they had a very close alliance (Suttner 1997:282f).

Most South African Jews at the time seemed to have been in favour of the South African-Israeli relationship, usually for pragmatic reasons. For Helen Suzman, seasoned politician, it was in essence a question of survival. While not condoning it, she could understand it. In her interview with Geoff Sifrin she explains herself:

Well, I took a more pragmatic view about this because, you know, people have to survive. I was once asked by Bishop Tutu, 'How could the Jews, Israel, with its history of Jewish persecution, have any dealings with a country like South Africa which is full of race discrimination?' And my answer was, "It was purely a question of survival!" (Suttner 1997:433).

\section{Apartheid and the Holocaust}

Asked by Sifrin if Tutu was satisfied with her answer, she answered negatively: "No, I'm sure it didn't". Suzman added: "When he (Tutu) used to compare the treatment of blacks by the government 
here with the Holocaust, that used to irritate me very much indeed..." (Suttner 1997:433). When Sifrin wanted to know why she found it impossible to compare apartheid with the Holocaust, Suzman expressed herself strongly:

I don't think it is possible, or useful. I think it is harmful. Because although there is no doubt that blacks were persecuted and oppressed and denied equal opportunities, there was never an actual attempt at genocide. And that is the real difference. It is true that a lot of babies die of malnutrition and a lot of people who were forcefully removed were starving in the rural areas...but they are not comparable situations, because the intention was not to wipe out the blacks. The system of apartheid was a totally heartless system which didn't care what the results were, but nevertheless it wasn't the practical implementation of genocide, and that was the difference. I did say that to Tutu, because he once compared apartheid to the Holocaust in front of a delegation from the American Jewish Congress. They were furious with him (Suttner 1997:433).

Suzman touched a raw nerve, for comparisons between the Holocaust and apartheid were very often made during the Truth Commission hearings. Not only Desmond Tutu, but most black politicians, including Nelson Mandela, was fond of doing that.

Judge Chaskalson, however, shared Suzman's opinion. There were indeed similarities, but the real difference was: the Holocaust consisted of deliberate murder, with the intention of eliminating the entire community. Apartheid, evil as it was, was different. Pressed to answer whether the difference was simply a matter of degree, or of quality, Chaskalson reacted:

I find it very hard to answer that one. You see, if you look at the Nüremberg Laws, and at the techniques that the Nazis used initially to marginalize Jewish communities, they were very similar to the techniques used by the Nationalists. The whole thing was there! Secondly, there was the element of racial superiority and racial inferiority. That's there, too. Thirdly, the difference arises that under the Nazis there was the deliberate attempt to kill all Jews in Europe. Under apartheid, the 
intention was to marginalise and disempower, and it led to enormous numbers of deaths - if you think of infant mortality and matters like that - but this happened as a by-product, not as a direct intention (Suttner 1997:330).

\section{In hindsight}

Was, then, the South African Jewish community guilty of abetting apartheid? Just how complex the answer to that question is, is clear from the discussion above. Suffice to quote Rabbi Harris, who - after arguing the case of his community admirably before the TRC ended the first part of his submission with a confession:

Nevertheless, with hindsight, it can be maintained that the community as a whole should have spoken out sooner than it did in condemning the large-scale violations of human rights which occurred in South Africa.

It is also true that more could and should have been done to help the oppressed. The organized Jewish community could have mobilized its considerable capacities and talents in the commercial, educational and welfare fields, to better effect (Harris 1997:270).

\section{JEWISH INVOLVEMENT IN THE STRUGGLE AGAINST APARTHEID}

In which ways did the Jewish community oppose gross human right abuses?, was one of the questions posed by the TRC Commissioners. Cyril Harris quoted Kadar Asmal, the then South African Minister of Water Affairs and Forestry, in this regard.

\section{Activists and heroes of the struggle}

At the launch of the book Cutting Through the Mountain (May 1997) the minister saluted the Jewish heroes of the struggle: "The Jewish community of South Africa has produced proportionally more heroes in the struggle against apartheid than any other socalled white group". For many years during the apartheid era, Asmal said, leading Jewish activists had suffered terribly by going against the tide. "Some were imprisoned for long periods; some went into exile, some were martyred such as Ruth First, and some were almost martyred such as Albie Sachs. Many lost their livelihoods and the special branch gave them undivided, almost extra, attention" (Harris 1997:270). 
In the book the names of twenty-seven of the heroes, those who were interviewed, are mentioned: the unionists Taffy Adler, Ray Alexander Simons and Pauline Podbrey; the artists and writers Johnny Clegg, Nadine Gordimer, Barney Simon, Irwin Manoim and Anton Harber; the activists David Bruce, Laurence Neill Nathan and the Coleman Family; the 'great dreamers' Joe Slovo, Gill Marcus, Ronnie Kasrils and Jack Flior; those who fought the legal battles, Isie Maisels and Arthur Chaskalson; the 'real heroes' of the struggle Albie Sachs, Rowley Israel Arenstein, Insa Perlman, Helen Suzman and Shawn Slovo, those who were imprisoned, Denis Goldberg, Raymond Suttner and Maxine Hart, as well as the teachers and preachers, Franz Auerbach and Ben Isaacson.

Other names may be added to the list, including Judge Richard Goldstone whose landmark judgments often defeated the objectives of, inter alia, the notorious Group Areas Act. There were other rabbis as well, leaders like Cyril Harris himself, who were willing to stand up against the powers that were: Rabbi André Unger of the Port Elizabeth Reform Congregation who was expelled by the government in 1955, Rabbi Eugene Duschinksy of the Cape Town Beth Din who vehemently protested against conditions in the local squatter camps (1979), Richar Lampert who was pulled from the pulpit by members of his own congregation and whose house had been raided by the police, as well as Arthur Saul Super, David Rosen and Selwyn Franklyn who constantly championed the cause of the under-privileged (Harris 1997:270, Suttner 1997:615).

Pride of place, however, goes to the late Chief Rabbi Louis Rabinowitz who ministered in Johannesburg from 1945-1961, whose words were noted at the TRC hearing:

When it comes to the question of apartheid, my conscience will not let me rest. I cannot accept that the colour of a man's skin shall dictate what privileges he may or may not enjoy. I know that discrimination is not confined to one party but has formed part of the policy of every South African government. I know there is a historical background to it, and that it will not disappear overnight. I am nevertheless convinced that it is ethically wrong and that is my duty as a rabbi to say so (Harris 1997:270). 
It is noteworthy - Cyril Harris testified at the TRC hearing - that more than half of the twenty-three whites involved in the Treason Trial in the 1950s, and all five whites apprehended in the Rivonia Arrests (1963) were Jewish. And although some Jews identified with the National Party, Jews overwhelmingly and continuously voted against the governing party, more than any other group in South Africa. Members of the Jewish community participated significantly in various protest groups such as the Five Freedoms Forum, Jews for Social Justice and the Black Sash (Harris 1997:271).

\section{The real hero: the ram}

Standing up against apartheid, was never easy. In a community where several churches supported apartheid, and where even the religious leaders of communities that suffered under apartheid were often passive - or worse, co-opted into the system - the achievement of the activists and the rabbis who did stand up to be counted was great. Immanuel Suttner who edited Cutting Through the Mountain brought homage to these men and women:

Against their own class interests, often against their own congregations an colleagues, against the difficult balances and the fear of rocking the boat, they chose not to turn a blind eye when they saw evil being done under the sun (Suttner 1997:619).

Often these heroes - as was the case with those from the other faith communities, Christians, Muslims, Hindus, et cetera - had to pay a price: ostracism, imprisonment, exile, martyrdom. They seldom looked for it, it happened to them. Yehuda Amichai wrote the following lines in his poem The Real Hero, lines that the editor of Cutting Through the Mountains thought aptly describe their position (Suttner 1997:341):

The real hero of the Isaac story was the ram,

who did not know about the conspiracy between the others.

As if he had volunteered to die instead of Isaac.

I want to sing a song in his memory -

about his curly wool and his human eyes, about the horns that were so silent on his living head, and how they made those horns into shofars after he was slaughtered... 
The angel went home

Isaac went home

Abraham and God had long gone before

But the real hero of the Isaac story

was the ram.

\section{TO REMEMBER AND TO RECONCILE: THE JEWISH CONTRIBUTION}

What is the specific contribution that the Jewish community can offer in terms of healing, reconciliation and nation building? At the TRC hearing each of the faith communities used the opportunity to discuss their role in this regard. There were high expectations. All future healing processes and reconciliation efforts deeply depend on the role of Christians, Jews, Muslims, Hindus, African traditionalists, and the rest, Archbishop Tutu emphasized. "Religion is central to the process of healing", Tutu wrote six months into the life of the TRC. "We need to reach the deep spiritual wells of our different religious traditions... to draw strength and grace with which to address the challenges of healing and nation building (Botman, Petersen 1996:8)

The idea of working together for such a lofty cause, is positive and inspiring - but should not be taken for granted. At the faith community hearings it was evident that being a member of one of the 'minority religions' in a South Africa that considered itself to be a 'Christian country', was not always easy. In Rabbi Harris' submission little was said about this. But the Muslim leader Farid Esack verbalized the feelings also of many Jews when he explained to the TRC that it was not only the security legislation that hurt the people. Christian 'triumphalism' was as big an issue. Being a 'nonChristian' in a 'Christian state' created all sorts of misunderstandings and problems.

Archbishop Tutu was aware of the hurt: "I am certain that all my fellow Christians in South Africa will agree with me if I express our deep apologies to you, the members of the other faith communities in the country, for the arrogant way in which we as Christians acted - as though ours was the only religion in South Africa, while we have been multi-religious from day one" (Meiring 1999:272). 
In proposing a role for the Jewish community, both Harris and the Gesher document pointed to a further complication: who can speak for the whole of the Jewish community? Jewish tradition is so rich and diverse, and much reliant on differing interpretations of its teachings and insights. There is thus no ultimate authority which can declare any interpretation to be that of all Jews (Gesher 1997:276). Nevertheless, there are a number of perspectives that can be helpful in our quest for reconciliation.

\section{The importance of not forgetting}

Since its inception the Truth and Reconciliation Commission was criticized by many: "Why do you want to rake up the past? Why can't you close the books and get on with life?" Tutu's answer usually was: "Of course we have to close the books. But the books must first be opened - before they finally can be closed". It was necessary to open the books, to remember the past for various reasons: the truth about the atrocities of the past had to be discovered, lessons for the future needed to be learned. Victims needed the opportunity to tell their stories, it became part of their healing process. Perpetrators were required to be candid and transparent in their testimonies, their amnesty applications depended on that.

The Jewish community who through the centuries suffered so much through the persecutions and pogroms of the past, the terror of the Holocaust during the 1930s and 1940s, goes one level deeper when the need to remember is mentioned. We need to remember for our own sake, to assuage our personal and collective guilt for having been saved, not having been killed. It also reminds us of our solemn obligation to the dead, to keep the flame alight and to hand on the spirit of hope to generations to come. During the TRC at the annual Yom Hashua occasion held in the Jewish cemetery in Rebecca Street, Pretoria (4 May 1997), Judge Ralph Zulman quoted the words of the Jewish sculptor Ernest Ullman on the memorial plaque at the Yad Vashem Memorial Centre in Johannesburg:

When I remember the dead, I am awed to have been saved. Is there not a feeling of guilt in all of us to be alive? Why were we singled out for this blessing? Were we better than those who died and were we more worthy than they to be spared the bitterness of the final sacrifice? 
We ask forgiveness from the dead for having failed them and abandoned them. We want to remember their suffering because it could perhaps have been our fate as well.

To be spared implies an obligation. It is the duty of the son to honour his parents and their memory - love will dictate his reverence. But more than that - is it not also the sacred obligation of the living to keep the flame alight, to carry the torch, to hand on the spirit of hope to others, so that it may not be extinguished, so that the last sighs of those who have perished be heard and preserved and not be lost forever in nothingness? (Meiring 1999:132)

\section{Who needs to reconcile?}

The Gesher submission joined the current debate in South Africa. Who are the guilty? Who are in need of reconciliation? Only the perpetrators who implemented and enforced the brutal system of apartheid - the politicians and the security policemen? According to Gesher, Jewish teaching on this point is clear: all of us need forgiveness and reconciliation.

Those who committed gross human rights abuses in the name of apartheid - the politicians, the officers, the soldiers and the policemen, the prison guards - should be the first to ask for reconciliation. It is no excuse to protest that they were merely obeying orders, or that they were politically motivated, believing that they were fighting for a just cause. Judaism insists that each individual is responsible for his or her actions.

The second category are those who consider themselves to be neither victims or perpetrators, but 'innocent bystanders'. There are many who claim that they bear no responsibility for what happened under apartheid, because they were not active instigators or implementers of the apartheid system, but simply tried to live their private or community lives in the South Africa of their day. This view must be rejected. According to Jewish teaching, all South Africans bear responsibility for what happened under apartheid:

An important Jewish teaching says that if a man is murdered in the field, then the elders of the nearest village will be held responsible for his death and for his 
burial, since it is their duty to ensure that the area in which they live is safe for themselves as passers-by. In other words, being part of a society in which atrocities are committed means that you cannot claim the status of an innocent bystander. We accept that we all should have striven to prevent such atrocities from occurring. This includes members of the Jewish community as well as other communities (Gesher 1997:276).

Jewish history, the Gesher submission reminded the TRC, is rife with examples of persecution - most recently in the Nazi Holocaust - in which surrounding populations stood by and did nothing, later claiming that they did not know what was happening. In South Africa all of us need to take the appropriate responsibility for the system under which we lived, for the atrocities committed under the system, and for the process of reconciliation (Gesher 1997:276f).

Thirdly, the victims of apartheid, as well as those who struggled against the system, need to accept their responsibility for the reconciliation process. A central notion in Judaism is teshuvah, which is usually translated as 'repentance', but which means 'turning' or 'returning'. It demands of all of us - no matter how ethical we believe our behaviour to have been - to examine ourselves, to discover where we have erred. It requires from the victims and those who fought the system alike, to 'return' to their own selves. Jewish teaching goes further: if victims and fighters against apartheid claim to have suffered and fought on a higher moral standard - because their cause was just - they are also expected to bind themselves to higher standards than others. It was this concern that led the author Elie Wiesel, himself a victim of unimaginable cruelty in Nazi concentration camps, to demand that the death sentence on the Nazi Adolph Eichmann not be implemented, arguing that Jews can only defeat the ideologies of their oppressors by showing that they were committed to higher ethical standards (Gesher 1997:277).

\section{The process of reconciliation}

In explaining the Jewish teaching on the reconciliation process, the Gesher submission referred the TRC to the 'Laws of Repentance' in the Mishneh Torah of Maimonides (Chapter 2):

(9)... But sins committed by one person against another, eg bodily injury, cursing, robbery, etc, will only be 
forgiven when the injured part has been fully satisfied. Even when one has carried out full restitution, there is still a need to seek forgiveness.

(10) It is wrong for a man to be cruel and refuse to be pacified. He should rather be ready to forgive and should be willing to forgive with a full heart and a willing soul. Even when one has been sorely injured one should not be vengeful...

(11) If one injured another in any way and the injured party died before restitution could be made or forgiveness granted, one must confess sin before a group of ten persons and one must offer restitution to the heirs of the injured party (Gesher 1997:281).

For reconciliation to happen, people have to face each other. The offended party must be willing to offer forgiveness. Forgiveness does not mean that we accept or accommodate the evil that has been perpetrated. Rather, without in any way condoning the act, forgiveness is the ability to let go of the resentment towards the person responsible. It you don't do that, you are not free. There still is a lot of resentment in South Africa today. Virtually all sections of society harbour these resentments. Victims as well as perpetrators are crippled by their resentments. In order to move towards reconciliation, Gesher called upon all South Africans, as a national priority, to explore ways to help people to understand one another's resentments, and to find ways of getting rid of these feelings, so that we can be free to build a healthy, strong society.

The role of the TRC in bringing people together, really to meet, to talk, to understand, to reach out and forgive, according to the Gesher statement, was limited. The TRC process was too public and 'confrontational'. "Genuine change and catharsis can only occur to a limited extent under TV cameras". The work of reconciliation therefore has to be passed on to the faith communities and other groups in society, challenging them to develop their own "truth and reconciliation commissions', to carry on, on a local and more personal level. The public catharsis being brought about by the TRC hearings, needed to become deeply rooted through a more detailed, grassroots process (Gesher 1997:279).

This sentiment has been echoed by many, during the TRC process, as well as after the TRC Report was published. The meeting 
of people, the story-telling, will have to continue for many years. At the end 21400 victims have submitted their statements (Meiring 1999:37). Many used the opportunity to address a public hearing. A large number found it, although painful and often agonizing, to be a healing process. But they still need counseling and guidance - and will for a long, long time. Moreover, millions of other South Africans who also suffered, who too were frustrated and angered by the cruelty and stupidity of the apartheid era, who were forcefully removed from their homes, who suffered abuse from many sides, too, need an opportunity to speak. As is the case with thousands of whites, who also suffered, who also lost their beloved in the struggle - or who are embarrassed by the past, and by their role during the apartheid era. The process has to continue, 'mini TRCs' need to be organised in every community - and the best place to do that, is the faith communities in the country.

\section{"The world endures on three things - justice, truth, and peace"}

Rabbi Shimon ben Gamaliel observed in the Talmud: "The world revolves on three things - justice, truth and peace". Each of these concepts is of extreme importance in the Jewish tradition, the Gesher submission stated. They may also, in a special way, offer an unique contribution to solving the many challenges South Africans are facing today. For Jews, all three concepts are the outcome of contact or relations between human beings. While the world is ordered by God, humanity is commanded to enter into a partnership with the Almighty, and to accept responsibility for perfecting the world. This means that we have to rely on our own reason and our own relationships to arrive at a human application of the Divine attributes of Justice, Truth and Reconciliation.

Taking the three concepts in reverse order: Reconciliation (peace) between human beings cannot be achieved by Divine intervention - or, indeed, by any intermediary. The person or group that has committed a wrong can only rectify it by making peace directly with the person or group wronged. This means that reconciliation cannot be dictated by law or by a commission - not even the Truth and Reconciliation Commission. It is the outcome of a sincere willingness of men and women to reconcile, born out of a sense of remorse for the wrongs of the past, and a desire not to repeat them. 
Justice is Judaism's primary social value. And, again, despite Judaism's firm belief in Divine justice, on the human level justice is the outcome of an agreement between human beings on a set of rules by which society should be ordered. The central test for civilised society is this agreement between human beings on the set of rules that govern these relationships - and willingness to apply them fairly to all in a court of justice. Justice should not be confused with vengeance:

The Jewish philosopher Emmanuel Levinas points out that historically the much misunderstood Jewish command to extract an 'eye for an eye' was not a call for vengeance, but rather an attempt to restrict it. In Talmudic tradition, in Jewish jurisprudence, 'an eye for an eye' is simply a legal term referring to financial compensation for a wound. It is natural for somebody who has suffered a wound (such as the people in this country) to react with vengeance, but to pursue a constant cycle of vengeance is to reduce us to barbarism. Therefore, victims are compelled, within an orderly society, to accept that society will operate only in terms of justice, not vengeance (Gesher 1997:280).

The same principle applies to Truth. Truth, in Judaism, is seen as a matter to be refined by debate between morally responsible individuals, since God has charged humanity with reaching its own understanding of truth. Jews in general - the Gesher submission reminded the 'Truth Commission' - tend to be suspicious of those who claim to have 'discovered the truth', and seek to impose it on their fellow human beings. "A Jewish commentary on the Creation suggests too that humane-ness is a greater value than truth, again warning us against the danger of harsh, human-inspired, concepts of 'absolute truth"' (Gesher 1997:280).

That these concepts are holding important lessons for South Africa today, goes without saying. If true reconciliation is to be achieved in our country - in our battered and divided society which is only just beginning to heal - we need to move towards a shared sense of justice, truth and reconciliation. And in a time when these principles have become blurred and often misunderstood - even devalued by being used too often and too easily - South Africans will do well, to rediscover the Jewish understanding and definition of the terms. 


\section{CONCLUSION}

When the Chief Rabbi left the TRC podium, Desmond Tutu invited his fellow commissioners to enter into a discussion with Cyril Harris. Numerous questions were asked and views exchanged. It was evident that the Jewish submission was of great interest to the Commission as well as to the audience. The next morning, in the national press, Harris's testimony before the TRC was widely reported and reflected upon.

The discussion of the Jewish role during the apartheid years, as well as its contribution in the reconciliation process, has to continue. The TRC, in its Final Report expressed high hopes for what may be done in South Africa to promote healing and reconciliation - calling upon the faith communities to fulfill a unique role in this regard. Among the recommendations were a number of challenges to the different faith communities:

- to communicate with one another to jointly eliminate religious conflict and to promote interreligious understanding;

- to seek ways to incorporate marginalized groups into their communities;

- to promote a culture of tolerance and peaceful coexistence;

- to inspire members to join forces in a peace corps, helping communities in need;

- to organize religious ceremonies, creating liturgies of healing and reconciliation;

- to develop theologies designed to promote reconciliation in order to develop a true sense of community among all South Africans (TRC Report, Volume 5, 1998:316ff).

To do this will keep the best of minds in the different communities occupied for years to come. But it has to be done with integrity, mutual understanding and respect, and a strong commitment to the faith communities - and faiths - we represent. And to the country to whom we owe our allegiance! The Christians as well as the other communities need to take cognizance of the Jewish contribution to reconciliation and nation building. Jews, though small in number, 
should with energy dialogue with 'the others'. Of course there will be differences, in style as well as in perspective. And Jews, as is the case with Muslims, will want to discuss their perception that Christians seem to be far too willing - because of their doctrine of free grace - to dish out forgiveness, to allow perpetrators to go free, without proper attention to the demands of justice. Christians, in turn, may want to challenge some of the Jewish presuppositions especially the notion that the Almighty has placed the responsibility for achieving justice, truth and reconciliation solely on our human shoulders, that Divine intervention should not be expected. And that in the face of the chairperson of the TRC who repeatedly rejoiced in the way in which the God of surprises worked reconciliation in situations we never expected it to happen! (Meiring 1999:126. For dialogue between Jews, Muslims and Christians in other countries, cf Marx 2002:93ff, and Wessels 2002:134ff ).

It is imperative that this discussion of the principles of justice, truth and reconciliation should continue, as it is equally important that Jews, Christians, Muslims, Hindus, African Traditionalists, and all the other faith communities should reach out to one another in their joint efforts to address the pressing needs of our country, and to work towards healing and reconciliation. Rabbi Cyril Harris' closing words was a declaration of a commitment that men and women of all faith communities need to make their own: "Bridge-building efforts require time and perseverance, but the Jewish community is keen to participate in all programmes which will alleviate tensions and help make our rainbow nation a reality" (Harris 1997:272).

\section{Consulted literature}

Botman, H R \& Peterson, R 1996. To Remember and to Heal. Cape Town: Human and Rousseau.

Boraine, A 2000: A Country Unmasked. Oxford: OUP.

Harris, C 1997: Truth and Reconciliation Commission: Submission by the Jewish Religious Community. Faith Community Hearing, East London, 1719 November 1997 (The numbering of the pages corresponds to the numbers used in the Agenda of the TRC Hearing).

Hendriks, J \& Erasmus, J 2002: 'A general statistical picture of religion in South Africa' in No quick fixes. Pretoria: ISWEN, 13-30.

Marx, T 2002. 'Theological Preparation for Reconciliation in Judaism, in Gort, J D (ed). 2002, Religion, Conflict and Reconciliation. Amsterdam: Rudopi, 93-103. 
Meiring, P (ed) 1996. A World of Religions. A South African Perspective. Pretoria: Kagiso.

-, 1999: A Chronicle of the Truth Commission. Vanderbijlpark: Carpe Diem.

South African Truth and Reconciliation Commission 1998/2003: Report, Volumes 1-7. Cape Town: TRC.

Suttner, I (ed) 1997. Cutting through the mountain. Interviews with South African Jewish Activists. London: Viking.

Tutu, D 1998: No future without forgiveness. London: Rider.

Wessels, A 2002. Can the Children of Abraham be Reconciled, in Gort, J D (ed). Religion, Conflict and Reconciliation. Amsterdam: Rudopi. 